\title{
The Effect of Thyroxine Therapy on Cardiovascular Risk Factors in Patients with Subclinical Hypothyroidism
}

\author{
Selvihan BEYSEL ${ }^{1}$ 國, Mahmut APAYDIN ${ }^{1}$ 國, Mustafa ÇALIŞKAN ${ }^{2}$ 國, Mustafa ÖZBEK ${ }^{3}$ 國, \\ Erman ÇAKAL $^{3}$ 國
}

\begin{abstract}
Aim: Subclinical hypothyroidism (SH) has a deleterious effect on cardiovascular risk factors (CVR); however it should be treated or not is stil controversial. The aim of our study is to determine CVR in patients with SH, and to investigate the short term effect of thyroxine treatment on CVR.

Material and Methods: Patients with SH $(n=30)$, and age- and sex-matched control group $(n=40)$ were included in this retrospective study. SH patients were treated by $50 \mu \mathrm{g}$ /day thyroxine for 3 months. Pre-treatment CVR was compared with post-treatment CVR.

Results: Sex distribution and mean age were similar between control (female 66.7\%; age 45.76 \pm 14.55 years) and $\mathrm{SH}$ (female 77.3\%; age 45.23 \pm 12.02 years) groups ( $>0.05$ ). Body mass index (BMI) was high in SH group (32.66 \pm 5.57 $\mathrm{kg} / \mathrm{m} 2)$ than in control group $(25.13 \pm 3.20 \mathrm{~kg} / \mathrm{m} 2, \mathrm{p}<0.05)$. At baseline, serum glucose $(83.76 \pm 9.51 \mathrm{vs} 91.73 \pm 9.96$ $\mathrm{mg} / \mathrm{dl})$, total cholesterol $(162.36 \pm 13.41$ vs $184.21 \pm 51.91 \mathrm{mg} / \mathrm{dl})$, low-density lipoprotein-cholesterol (LDL-C; $91.73 \pm 22.04$ vs $104.61 \pm 11.36 \mathrm{mg} / \mathrm{dl}$ ), and C-reactive protein (hs-CRP; $1.53 \pm 0.66$ vs $2.63 \pm 0.93 \mathrm{mg} / \mathrm{L}$ ) levels were higher in SH group than in the control group $(\mathrm{p}<0.05)$. After treatment, BMI value decreased $(31.35 \pm 5.54 \mathrm{~kg} / \mathrm{m} 2) \mathrm{along}$ with decreasing serum LDL-C $(97.30 \pm 9.63 \mathrm{mg} / \mathrm{dl})$ and hs-CRP $(1.96 \pm 0.42 \mathrm{mg} / \mathrm{L})$ levels in SH group (p<0.05). Thyroid stimulating hormone was independently associated with LDL-C (OR=2.17,\%95CI [1.26-2.54], $\mathrm{p}=0.005)$.

Conclusion: In this study, it was determined that cardiometabolic disorders in patients with subclinical hypothyroidism partiel improved with thyroxine treatment. Thyroxine treatment may contribute to the reduction of increased cardiovascular risk in subclinical hypothyroidism.
\end{abstract}

Keywords: Subclinical hypothyroidism; cardiovascular risk factors; thyroxine therapy

ÖZ

\section{Subklinik Hipotiroidili Hastalarda Tiroksin Tedavisinin Kardiyovasküler Risk Faktörleri Üzerine Etkisi}

Amaç: Subklinik hipotiroidizm (SH) kardiyovasküler risk faktörleri (KVR) üzerinde zararlı bir etkiye sahiptir; ancak tedavi edilip edilmemesi halen tartışmalıdır. Çalışmanın amacı, SH hastaların KVR'ini belirlemek ve kısa süreli tiroksin tedavisinin bunlara etkisini araştırmaktır.

Gereç ve Yöntemler: Bu retrospektif çalışmaya $\mathrm{SH}$ grubu(n=30) ve yaş-cinsiyet eşleştirilmiş kontrol grubu (n=40) dahil edildi. SH hastalarına 3 ay boyunca $50 \mu \mathrm{g}$ /gün tiroksin tedavisi verildi. Tedaviden önceki KVR, tedaviden sonraki KVR ile karşılaştırıldı.

Bulgular: Kontrol (kadın \%66,7; yaş 45,76 $\pm 14,55$ y1l) ve SH (kadın \%77,3; yaş 45,23 $\pm 12,02$ yıl) grubu arasında, cinsiyet dağılımı ve yaş ortalaması benzerdi ( $\mathrm{p}>0,05)$. Vücut kitle indeksi (VKİ) SH grubunda $(32,66 \pm 5,57 \mathrm{~kg} / \mathrm{m} 2)$, kontrol grubundan $(25,13 \pm 3,20 \mathrm{~kg} / \mathrm{m} 2)$ daha yüksekti. Başlangiçta, $\mathrm{SH}$ grubunda serum glukoz $(83,76 \pm 9,51 \mathrm{vs} 91,73 \pm$

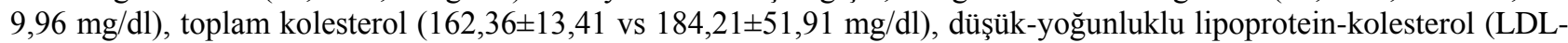
C; $91,73 \pm 22,04$ vs $104,61 \pm 11,36 \mathrm{mg} / \mathrm{dl}$ ), C-reaktif protein (hs-CRP; $1,53 \pm 0,66$ vs 2,63 $\pm 0,93 \mathrm{mg} / \mathrm{L}$ ) düzeyi, kontrol grubuna göre daha yüksekti $(\mathrm{p}<0,05)$. Tedaviden sonra, SH grubunda VKI değerinde $(31,35 \pm 5,54 \mathrm{~kg} / \mathrm{m} 2)$ azalma ile birlikte serum LDL-C $(97,30 \pm 9,63 \mathrm{mg} / \mathrm{dl})$ ve hs-CRP $(1,96 \pm 0,42 \mathrm{mg} / \mathrm{L})$ düzeyi azaldı $(\mathrm{p}<0,05)$. Tiroid stimulan hormon, bağımsız olarak LDL-C ile ilişkiliydi (OR=2,17,\%95 CI [1,26-2,54], p=0,005).

Sonuç: Bu çalışmada, SH'li hastalarda kardiyometabolik bozuklukların tiroksin tedavisi ile kısmen düzeldiği gösterildi.

1 Department of Endocrinology and Metabolism, Afyonkarahisar Health Sciences University, Afyonkarahisar, Turkey

2 Department of Endocrinology and Metabolism, Düzce Atatürk State Hospital, Düzce, Turkey

3 Department of Endocrinology and Metabolism, University of Health Sciences, Diskapi Yildirim Beyazit Training and Research Hospital, Ankara, Turkey

Sorumlu Yazar / Corresponding Author: Selvihan Beysel, e-mail: beyselselvihan@gmail.com

Geliş Tarihi / Received: 30.08.2019, Kabul Tarihi / Accepted: 03.04.2021 
Tiroksin tedavisi, subklinik hipotiroidide artmış kardiyovasküler riskin azaltılmasına katkıda bulunabilir.

Anahtar Kelimeler: Subklinik hipotiroidi; kardiyovasküler risk faktörü; tiroksin tedavisi.

\section{INTRODUCTION}

Subclinical hypothyroidism is defined as high serum thyroid-stimulating hormone (TSH) with normal levels of free thyroxine (FT4) and free triiodothyronine (FT3) (1). Subclinical hypothyroidism is generally classified as mild (4-10 $\mathrm{mIU} / \mathrm{mL})$ and severe $(>10 \mathrm{mIU} / \mathrm{mL})$ according to TSH levels (2). The prevalence of subclinical hypothyroidism in adults is $4-20 \%$ (3). Its prevalence increases with age, and it reaches $20 \%$ in women over 60 years of age $(1,2)$. Approximately $2-5 \%$ of these patients progress to evident hypothyroidism every year (4). Patients with subclinical hypothyroidism are mostly asymptomatic; however, clinical, biochemical and functional findings of thyroid hormone deficiency appear in patients with subclinical hypothyroidism $(1,3)$. Subclinical hypothyroid patients have symptoms included fatigue, poor memory, muscle weakness, cold intolerance, constipation, and dry skin $(1,5)$. Patients with subclinical hypothyroidism exert adverse metabolic, cardiovascular, and maternal-fetal abnormalities $(1,3,6)$. Evidence suggests that subclinical hypothyroidism has a detrimental role on cardiovascular risk factors (7). Subclinical hypothyroidism has been reported to be associated with an increased risk of metabolic syndrome, diabetes and obesity $(3,7,8)$. Patients with subclinical hypothyroidism were associated with an increased risk of atherosclerosis, myocardial infarction, cardiovascular disease, and cardiovascular mortality $(3,8)$. Currently, the treatment of subclinical hypothyroidism remains controversial $(8,9)$. Thyroxine treatment has been reported to be beneficial in some studies, but others studies have not shown any benefit of treatment (9). It has been observed that thyroxine treatment decreases cardiovascular risk and mortality in patients with subclinical hypothyroidism under 65 years of age, especially in patients with $\mathrm{TSH}>10 \mathrm{mIU} / \mathrm{mL} \quad(2,6)$. Despite observational studies, there is no evidence that the mild form of subclinical hypothyroidism improves lipid profiles and other cardiometabolic risk factors (6).

There is still no consensus on the clinical significance of adverse conditions in patients with mild form of subclinical hypothyroidism and the benefit of thyroxine treatment (6). The aim of this retrospective study was to determine whether there is a relationship between subclinical hypothyroidism and cardiovascular risk factors, and also to investigate the short effects of thyroxine treatment on cardiovascular risk factors in patients with subclinical hypothyroidism.

\section{MATERIAL AND METHODS}

Patients with subclinical hypothyroidism treated in the Department of Endocrinology and Metabolism at Ankara Diskapi Training and Research Hospital were enrolled to this retrospective study. Patients with subclinical hypothyroidism $(\mathrm{n}=30)$, and age- and sex-matched healthy controls with having normal thyroid functions $(n=40)$ were included to the study. Patients with subclinical hypothyroidism treated by $50 \mu \mathrm{g} /$ day thyroxine for 3 months. Patients who did not use thyroxine treatment were excluded from the study. Patients with liver disease, renal failure, diabetes, malignancy, familial dyslipidemia, under 18 years of age and over 75 years of age, pregnant women, and non-compliant patients were not included to the study. Patients receiving oral contraceptive drugs were not included. Demographic characteristics, biochemical, and hormonal results of all participants' baseline and 3 months after thyroxine treatment were recorded. In the subclinical hypothyroid group, the results were compared before and after thyroxine treatment. Body mass index of (BMI) all participants were calculated by body weight $(\mathrm{kg}) /$ height (m2). Office blood pressure (BP) was measured in each subjects at the sitting position at the level of the heart. A cuff covered about $80 \%$ of the circumference of the upper arm with the lower edge 2.5-3.0 $\mathrm{cm}$ above the elbow. Fasting blood glucose, low-density lipoproteincholesterol (LDL-C), high-density lipoprotein cholesterol (HDL-C), total cholesterol, triglyceride, and C-reactive protein (hs-CRP) were measured after overnight fasting. Normal serum values were considered as serum value of TSH: 0.4-4.0 mIU/ml, FT3: $1.8-4.2 \mathrm{ng} / \mathrm{dl}$, and FT4: 0.8$1.9 \mathrm{ng} / \mathrm{dl}$. Patients with having serum TSH value $>4.0$ $\mathrm{mIU} / \mathrm{ml}$, with normal range of serum FT3 and FT4 value were included in the subclinical hypothyroid group. Each subject gave written informed consent in accordance with the Declaration of Helsinki. This study was approved by the Diskapi Teaching and Training Hospital Local Ethic Committee (16.02.2015-12/25).

\section{Statistical Analysis}

Statistical analysis was performed by using SPSS 18.0 (SPSS, Inc) software. Descriptive statistics awere expressed as mean \pm standard deviation (SD), percentages (\%), odds ratio (OR), $95 \%$ confidence intervals (CI). Shapiro-Wilk W-test was used for normality. Chi-square test was used for categorical variables. Student's t test was used for normally distributed continuous variables or log-transformed variables between two groups. The paired-samples t-test was used for the two groups before and after thyroxine treatment. Logarithmic transformation was used on continuous variables that were not normally distributed. Spearman's and Pearson's Correlation analyses were performed for the relationships between variables. Backward logistic regression was performed: TSH was defined as dependent variable and gender, age, glucose, BMI, LDL-C, total cholesterol, and hs-CRP were independent variables. Study sample size was determined by PASS software (NCSS, Inc). Statistical significance was defined as a $\mathrm{p}<0.05$.

\section{RESULTS}

Sex distribution and mean age were similar between controls (female $66.7 \%$; age $45.76 \pm 14.55$ years) and the patients with subclinical hypothyroidism (female $77.3 \%$; age $45.23 \pm 12.02$ years) groups ( $p>0.05$ for each). At baseline, BMI was higher in subclinical hypothyroidism group $(32.66 \pm 5.57 \mathrm{~kg} / \mathrm{m} 2)$ than in control group $(25.13 \pm 3.20 \mathrm{~kg} / \mathrm{m} 2, \mathrm{p}<0.05)$. After the treatment, BMI $(31.35 \pm 5.54 \mathrm{~kg} / \mathrm{m} 2)$ was significantly decreased $(\mathrm{p}<0.05)$. At baseline, serum TSH level was significantly higher in subclinical hypothyroidism group compared 
with control group $(6.29 \pm 1.53$ vs $2.35 \pm 0.95 \mathrm{mIU} / \mathrm{ml}$, $\mathrm{p}<0.05)$. Serum FT4 $(1.18 \pm 0.17$ vs $1.16 \pm 0.17 \mathrm{ng} / \mathrm{dl})$ and FT3 $(3.3 \pm 0.61$ vs $3.2 \pm 0.72 \mathrm{ng} / \mathrm{dl})$ were similar between groups ( $>0.05$ for each). After treatment, serum TSH level was significantly decreased $(3.21 \pm 1.30 \mathrm{mIU} / \mathrm{ml}$, $\mathrm{p}<0.05)$, whereas FT4 significantly increased $(1.28 \pm 0.20$, $\mathrm{p}<0.05)$, and FT3 did not change $(3.5 \pm 0.92 \mathrm{ng} / \mathrm{dl}$, $\mathrm{p}>0.05)$. At baseline, serum glucose $(83.76 \pm 9.51$ vs $91.73 \pm 9.96 \mathrm{mg} / \mathrm{dl})$, total cholesterol $(162.36 \pm 13.41 \mathrm{vs}$ $184.21 \pm 51.91 \mathrm{mg} / \mathrm{dl}), \quad$ LDL-C $\quad(91.73 \pm 22.04 \quad$ vs $104.61 \pm 11.36 \mathrm{mg} / \mathrm{dl})$, and hs-CRP $(1.53 \pm 0.66$ vs $2.63 \pm 0.93 \mathrm{mg} / \mathrm{L})$ levels were significantly higher in subclinical hypothyroidism group than in control group $(\mathrm{p}<0.05)$. After treatment, glucose $(86.76 \pm 8.48 \mathrm{mg} / \mathrm{dl})$, LDL-C (97.30 $\pm 9.63 \mathrm{mg} / \mathrm{dl})$, and hs-CRP (1.96 \pm 0.42 $\mathrm{mg} / \mathrm{dl}) \quad$ significantly decreased $(\mathrm{p}<0.05)$. Serum triglyceride and HDL-C were similar between groups at baseline ( $>0.05$ for each). After the treatment, total cholesterol, triglyceride, and HDL-C levels did not change ( $>>0.05$ for each). Characteristics of the control group and subclinical hypothyroid group before and after the L-thyroxine treatment were shown in Table1.

Table 1. Characteristics of the control and subclinical hypothyroidism group before and after the thyroxine treatment

\begin{tabular}{|c|c|c|c|c|c|}
\hline & Controls $(\mathrm{n}=40)$ & $\begin{array}{l}\text { Subclinical } \\
\text { hypothyroidi } \\
\mathrm{sm} \\
\text { (before } \\
\text { treatment) } \\
(\mathrm{n}=30)\end{array}$ & $\begin{array}{l}\text { Subclinical } \\
\text { hypothyroidis } \\
\mathrm{m} \\
\text { (after } \\
\text { treatment) } \\
(\mathrm{n}=30)\end{array}$ & P* & $\mathrm{P}^{* * *}$ \\
\hline BMI $\left(\mathrm{kg} / \mathrm{m}^{2}\right)$ & $25.13 \pm 3.20$ & $32.66 \pm 5.57$ & $31.35 \pm 5.54$ & 0.002 & 0.029 \\
\hline $\begin{array}{l}\text { Systolic BP } \\
(\mathrm{mmHg})\end{array}$ & $132.46 \pm 12.56$ & $135.74 \pm 14.34$ & $132.56 \pm 12.56$ & 0.568 & 0.135 \\
\hline $\begin{array}{l}\text { Diastolic BP } \\
(\mathrm{mmHg})\end{array}$ & $87.59 \pm 8.57$ & $88.37 \pm 7.64$ & $87.63 \pm 8.43$ & 0.496 & 0.079 \\
\hline $\begin{array}{l}\text { TSH } \\
(\mathrm{mIU} / \mathrm{ml})\end{array}$ & $2.35 \pm 0.95$ & $6.29 \pm 1.53$ & $3.21 \pm 1.30$ & 0.001 & 0.001 \\
\hline FT4 (ng/dl) & $1.18 \pm 0.17$ & $1.16 \pm 0.17$ & $1.28 \pm 0.20$ & 0.725 & $\overline{0.004}$ \\
\hline FT3 (ng/dl) & $3.3 \pm 0.61$ & $3.2 \pm 0.72$ & $3.5 \pm 0.92$ & 0.886 & 0.056 \\
\hline $\begin{array}{l}\text { Glucose } \\
(\mathrm{mg} / \mathrm{dl})\end{array}$ & $83.76 \pm 9.51$ & $91.73 \pm 9.96$ & $86.76 \pm 8.48$ & 0.004 & 0.015 \\
\hline $\begin{array}{l}\text { Total } \\
\text { cholesterol } \\
(\mathrm{mg} / \mathrm{dl})\end{array}$ & $162.36 \pm 13.41$ & $184.21 \pm 51.91$ & $181.34 \pm 45.63$ & 0.032 & 0.078 \\
\hline $\begin{array}{l}\text { Triglyceride } \\
(\mathrm{mg} / \mathrm{dl})\end{array}$ & $154.58 \pm 43.87$ & $165.89 \pm 40.29$ & $159.63 \pm 28.47$ & 0.346 & 0.065 \\
\hline $\begin{array}{l}\text { LDL-C } \\
(\mathrm{mg} / \mathrm{dl})\end{array}$ & $91.73 \pm 22.04$ & $104.61 \pm 11.36$ & $97.30 \pm 9.63$ & 0.004 & 0.002 \\
\hline $\begin{array}{l}\text { HDL-C } \\
(\mathrm{mg} / \mathrm{dl})\end{array}$ & $41.23 \pm 3.99$ & $42.93 \pm 3.28$ & $43.40 \pm 2.84$ & 0.074 & 0.062 \\
\hline $\begin{array}{l}\text { hs-CRP } \\
(\mathrm{mg} / \mathrm{L})\end{array}$ & $1.53 \pm 0.66$ & $2.63 \pm 0.93$ & $1.96 \pm 0.42$ & 0.001 & 0.002 \\
\hline
\end{tabular}

P* controls vs subclinical hypothyroidism (before treatment) was compared with using Student's t-test $\mathrm{p}^{* *}$ subclinical hypothyroidism (before treatment) vs subclinical hypothyroidism (after treatment) was compared with using pairedsample t-test.

Data are presented as mean \pm Standart Deviations

Bold presents the significant $\mathrm{p}$-value.

BMI: Body mass index, BP: blood pressure, TSH: thyroid-stimulating hormone, FT4: free thyroxine, FT3: free triiodothyronine, LDL-C: lowdensity lipoprotein cholesterol, HDL-C: high-density lipoprotein cholesterol, hs-CRP: high sensitivity C-reactive protein.
TSH value was positively correlated with BMI $(r=0.371$, $\mathrm{p}=0.001)$, glucose $(\mathrm{r}=0.352, \mathrm{p}=0.002)$, LDL-C $(\mathrm{r}=0.412$, $\mathrm{p}=0.001)$, and hs-CRP $(\mathrm{r}=0.425, \mathrm{p}=0.001)$. TSH was not correlated with other cardiovascular risk factors including blood pressures, HDL-C, triglyceride, and total cholesterol (Table2).

Table 2. Correlation between the serum TSH and cardiovascular risk factors

\begin{tabular}{|l|l|l|}
\hline & $\mathrm{r}$ & $\mathrm{P}$ \\
\hline BMI $(\mathrm{kg} / \mathrm{m} 2)$ & $\mathbf{0 . 3 7 1}$ & $\mathbf{0 . 0 0 1}$ \\
\hline Glucose $(\mathrm{mg} / \mathrm{dl})$ & $\mathbf{0 . 3 5 2}$ & $\mathbf{0 . 0 0 2}$ \\
\hline Total cholesterol $(\mathrm{mg} / \mathrm{dl})$ & 0.268 & 0.234 \\
\hline Triglyceride $(\mathrm{mg} / \mathrm{dl})$ & 0.109 & 0.844 \\
\hline LDL-C $(\mathrm{mg} / \mathrm{dl})$ & $\mathbf{0 . 4 1 2}$ & $\mathbf{0 . 0 0 1}$ \\
\hline HDL-C $(\mathrm{mg} / \mathrm{dl})$ & 0.291 & 0.064 \\
\hline hs-CRP $(\mathrm{mg} / \mathrm{L})$ & $\mathbf{0 . 4 2 5}$ & $\mathbf{0 . 0 0 1}$ \\
\hline
\end{tabular}

$\mathrm{r}$ presents the correlation coefficient

Bold presents the significant p-value

BMI: Body mass index, TSH: thyroid-stimulating hormone, LDL-C: low-density lipoprotein cholesterol, HDL-C: high-density lipoprotein cholesterol, hs-CRP: high sensitivity C-reactive protein.

TSH was independently associated with the serum LDLC level. Logistic regression analysis of the serum TSH with variables are shown in Table3.

Table 3. Logistic regression analyses of serum TSH level and the cardiovascular risk factors

\begin{tabular}{|c|c|c|}
\hline Risk factors & 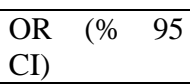 & $\mathrm{P}$ \\
\hline Age (year) & $\begin{array}{ll}1.03 & (1.00- \\
1.04) & \end{array}$ & 0.137 \\
\hline Gender (Female vs male) & $\begin{array}{ll}1.10 & (0.67- \\
1.74) & \end{array}$ & 0.714 \\
\hline BMI (kg/m2) & $\begin{array}{l}0.72 \\
1.23)\end{array}$ & 0.248 \\
\hline Glucose (mg/dl) & $\begin{array}{ll}2.66 & (0.62- \\
8.75) & \end{array}$ & 0.283 \\
\hline Total cholesterol (mg/dl) & $\begin{array}{l}1.45 \\
1.36)\end{array}$ & 0.797 \\
\hline LDL-C (mg/dl) & $\begin{array}{ll}2.17 & (1.26- \\
2.54) & \\
\end{array}$ & 0.005 \\
\hline hs-CRP (mg/L) & $\begin{array}{ll}0.98 & (0.82- \\
1.08) & \\
\end{array}$ & 0.362 \\
\hline
\end{tabular}

BMI: Body mass index, TSH: thyroid-stimulating hormone, LDL-C: low-density lipoprotein cholester7-ol, hs-CRP: high sensitivity Creactive protein, OR: odds ratio, CI: confidence interval

\section{DISCUSSION}

In our study, patients with the mild form of subclinical hypothyroidism had greater BMI, higher levels of serum glucose, total cholesterol, LDL-C, and hs-CRP compared with controls, at baseline. After the 3 months of the thyroxine treatment, BMI decreased along with decreasing LDL-C, and hs-CRP concentrations in the subclinical hypothyroid patients. TSH was positively correlated with the BMI, glucose, LDL-C, and hs-CRP. TSH value was independently associated with LDL-C in the logistic regression analyses.

Increased prevalance of dyslipidemia (2), hypertension (10), weight gain (11), metabolic syndrome (12), coronary artery disease (13), insulin resistance (14), endothelial dysfunction (15), increased carotid intima media thickness (16), and hypercoagulability and oxidative stress (17) are the possible causes of cardiovascular risk increase in patients with subclinical 
hypothyroidism. In our study, elevated BMI, serum glucose, LDL-C, and total cholesterol levels were found in subclinical hypothyroid patients. After treatment with thyroxine, LDL-C decreased along with BMI, but total cholesterol did not change. Furthermore, triglyceride and HDL-C levels were not different between subclinical hypothyroid patients and controls, and did not change after treatment. Similarly, Yetmiş et al found a decrease in BMI, decreased glucose and LDL-C on the thyroxine treatment in patients with subclinical hypothyroidism (4). The increase in TSH level increases the weight gain $(2,12)$. It was reported that elevation in TSH level is associated with an increase in BMI and occurrence of obesity (18).

In our study, logistic regression analysis was showed that serum TSH was independently associated with the serum LDL-C (OR=2.17, $95 \%$ CI [1.26-2.54], p=0.005); while TSH were not associated with other cardiovascular risk factors such as gender, age, glucose, BMI, total cholesterol, and hs-CRP. As serum TSH was independently associated with the LDL-C, TSH-related to cardiovascular risk factors caused by LDL-C associations. Thyroxine threapy affects lipid metabolism, and the lipid profiles deteriorates along with TSH levels (2). Several studies have reported that thyroxine treatment have improved lipid profiles in patients with subclinical hypothyroidism, which supports the findings of our study $(3,19)$. In metaanalysis, subclinical hypothyroidism showed a decrease of $9 \%$ in total cholesterol and $14 \%$ in LDL-C after the thyroxine treatment, which decreased the risk of coronary artery disease (3). Subclinical hypothyroidism affects the serum lipid profiles, with the effect of reducing LDL receptor expression, reducing the concentration of hepatic lipase, reducing the concentration of cholesterol ester transfer protein and reducing the hydroxymethylglutaryl coenzyme A reductase (2). Since LDL cholesterol is closely associated with an increased risk of cardiovascular disease, atherosclerosis and stroke; the reduction in LDL-C results in a reduction in the incidence of coronary artery disease (19).

It has been shown that thyroid hormone stimulates every stage of carbohydrate metabolism, increases the absorption of glucose from the gastrointestinal tract, increases the use of glucose by the cells, induces the brown adipose tissue; thus increases the insulin secretion $(4,20)$. In our study, serum glucose levels were found to be increased in patients with subclinical hypothyroidism compared with controls. Glucose levels both are in normal range before and after thyroxine treatment. Since they are not in diabetic range it is difficult to say it is a positive cardiovascular risk factor which is corrected by the thyroxine therapy. In our study, blood pressures are in normal range before and after treatment, and did not differ compared to controls. Ye et al reported that increased systolic blood pressure was observed in patients with subclinical hypothyroidism, which imcompatible with our result (21). Elevated levels of systolic and diastolic blood pressure as well as serum cholesterol in women with subclinical hypothyroidism improved after thyroxine treatment (22). CRP is a marker of low-grade inflammation, and it suggests as a risk factor for cardiovascular disease (5). Previous study reported that patients with subclinical hypothyroidism were associated with an increase in CRP and fibrinogen (7). In another studies conducted with subclinical hypothyroidism, thyroxine treatment was reported not to decrease elevated CRP (5,23). TSH value was positively correlated with BMI, LDL-C, glucose, hs-CRP value in our study. Previous studies have found a positive correlation between serum TSH and total cholesterol and LDL-C levels, which consistent with our study $(21,24)$. Because the increase in total cholesterol and LDL-C levels in subclinical hypothyroidism is correlated with an increase in TSH level to some extent, it may be determine the degree of thyroxine treatment response (3).

This retrospective study with small sample size, which is limitation of our study. The duration of the thyroxine therapy is short to analyze the accurate effect of treatment.

\section{CONCLUSIONS}

In our study, the presence of high BMI, LDL-C, hs-CRP levels in subclinical hypothyroid patients may contribute to increased cardiovascular risk factors associated with subclinical hypothyroidism. In our study, adverse cardiometabolic risk factors associated with subclinicalhypothyroidism partiel improved with short term thyroxine treatment. Long-term studies are needed to demonstrate the effects of thyroxine use on cardiovasular risk in the treatment of the mild form of subclinical hypothyroidism.

Acknowledgements: None

Abbreviations: BMI: Body mass index, BP: blood pressure, TSH: thyroid-stimulating hormone, FT4: free thyroxine, FT3: free triiodothyronine, LDL-C: lowdensity lipoprotein cholesterol, HDL-C: high-density lipoprotein cholesterol, hs-CRP: high sensitivity Creactive protein.

\section{Competing interests}

The authors declare that they have no competing interests.

Authors's Contributions: Idea/Concept: SB; Design: SB, MÇ; Data Collection and/or Processing: SB, MÇ; Analysis and/or Interpretation: MA, MÖ, EC; Literature Review: SB; Writing the Article: SB; Critical Review: SB, MÇ.

\section{REFERENCES}

1. Azim S, Nasr C. Subclinical hypothyroidism: When to treat. Cleve Clin J Med. 2019; 86(2): 101-10. https://doi.org/10.3949/ccjm.86a.17053.

2. Delitala AP, Fanciulli G, Maioli M, Delitala G. Subclinical hypothyroidism, lipid metabolism and cardiovascular disease. Eur J Intern Med. 2017; 38(1):

$17-24$. https://doi.org/10.1016/j.ejim.2016.12.015.

3. Abreu IM, Lau E, de Sousa Pinto B, Carvalho D. Subclinical hypothyroidism: to treat or not to treat, that is the question! A systematic review with metaanalysis on lipid profile. Endocr Connect. 2017; 6(3): 188-99. https://doi.org/10.1530/EC-17-0028.

4. Yetmiş M, Kazancıoğlu R, Erkoç R, Tükek T, Peru C, Çıkrıkçıŏlu MA. Subklinik hipotiroidili hastalarda lipid profili ve vücut kitle indeksinde değişiklikler; L-tiroksin tedavisinin 
değerlendirilmesi. Med Bull Haseki. 2011; 49(4): 131-6.

5. Bilgir O, Bilgir F, Calan M, Calan OG, Yuksel A. Comparison of pre- and post-levothyroxine highsensitivity c-reactive protein and fetuin-a levels in subclinical hypothyroidism. Clin Sao Paulo Braz. 2015; $70(2)$ :

97-101. https://doi.org/10.6061/clinics/2015(02)05.

6. Javed Z, Sathyapalan T. Levothyroxine treatment of mild subclinical hypothyroidism: a review of potential risks and benefits. Ther Adv Endocrinol Metab. 2016; 7(1): 12-23. https://doi.org/ $10.1177 / 2042018815616543$.

7. Güngüneș A, Çelik K, Şahin M, Özbek M, Çakal E, Çakır E et al. Kardiyovasküler risk faktörü olarak fibrinojen, yüksek duyarlılıklı C-reaktif protein ve lipid parametrelerinin subklinik hipotiroidili hastalardaki düzeyi. Turk J Clin Lab. 2016; 7(3). https://doi.org/10.18663/tjcl.34283.

8. Suh S, Kim DK. Subclinical hypothyroidism and cardiovascular disease. Endocrinol Metab Seoul Korea. $2015 ; \quad 30(3)$ : 246-51. https://doi.org/10.3803/EnM.2015.30.3.246.

9. Andersen MN, Olsen AMS, Madsen JC, Kristensen SL, Faber J, Torp-Pedersen C, et al. Long-Term outcome in levothyroxine treated patients with subclinical hypothyroidism and concomitant heart disease. J Clin Endocrinol Metab. 2016; 101(11): 4170-7. https://doi.org/10.1210/jc.2016-2226.

10. Jiang F, Liu A, Lai Y, Yu X, Li C, Han C, et al. Change in serum TSH levels within the reference range was associated with variation of future blood pressure: A 5-year follow-up study. J Hum Hypertens. 2417 ; 31(4): https://doi.org/10.1038/jhh.2016.59.

11. Fox CS, Pencina MJ, D'Agostino RB, Murabito JM, Seely EW, Pearce E, et al. Relations of thyroid function to body weight: Cross-sectional and longitudinal observations in a community-based sample. Arch Intern Med. 2018; 168(6): 587-92. https://doi.org/ 10.1001/archinte.168.6.587.

12. Taylor PN, Razvi S, Pearce SH, Dayan CM. Clinical review: A review of the clinical consequences of variation in thyroid function within the reference range. J Clin Endocrinol Metab. 2013; 98(9): 356271. https://doi.org/10.1210/jc.2013-1315.

13. Selmer C, Olesen JB, Hansen ML, von Kappelgaard LM, Madsen JC, Hansen PR, et al. Subclinical and overt thyroid dysfunction and risk of all-cause mortality and cardiovascular events: a large population study. J Clin Endocrinol Metab. 2014; 99(7): 2372-82. https://doi.org/10.1210/jc.20134184.

14. Maratou E, Hadjidakis DJ, Kollias A, Tsegka K, Peppa M, Alevizaki M, et al. Studies of insulin resistance in patients with clinical and subclinical hypothyroidism. Eur J Endocrinol. 2009; 160(5): 785-90. https://doi.org/10.1530/EJE-08-0797.

15. Razvi S, Ingoe L, Keeka G, Oates C, McMillan C, Weaver JU. The beneficial effect of L-thyroxine on cardiovascular risk factors, endothelial function, and quality of life in subclinical hypothyroidism: randomized, crossover trial. J Clin Endocrinol
Metab. 2007; 92(5):

https://doi.org/10.1210/jc.2006-1869.

1715-23.

16. Takamura N, Akilzhanova A, Hayashida N, Kadota $\mathrm{K}$, Yamasaki H, Usa $\mathrm{T}$, et al. Thyroid function is associated with carotid intima-media thickness in euthyroid subjects. Atherosclerosis. 2009; 204(2): e77-81.

https://doi.org/10.1016/j.atherosclerosis.2008.09.022.

17. Biondi B, Cooper DS. The clinical significance of subclinical thyroid dysfunction. Endocr Rev. 2008; 29(1): 76-131. https://doi.org/10.1210/er.2006-0043.

18. Knudsen N, Laurberg P, Rasmussen LB, Bülow I, Perrild H, Ovesen L, et al. Small differences in thyroid function may be important for body mass index and the occurrence of obesity in the population. J Clin Endocrinol Metab. 2005; 90(7): 4019-24. https://doi.org/10.1210/jc.2004-2225.

19. Teixeira PFS, Reuters VS, Ferreira MM, Almeida CP, Reis FAA, Melo BA, et al. Treatment of subclinical hypothyroidism reduces atherogenic lipid levels in a placebo-controlled double-blind clinical trial. Horm Metab Res Horm. 2008; 40(1): 50-5. https://doi.org/10.1055/s-2007-993216.

20. Takir M, Kizilgul M. Prevalence of metabolic syndrome in hypothyroid patients under levothyroxine therapy. Medeni Med J. 2018; 33(4): 252-62. https://doi.org/10.5222/MMJ.2018.02700.

21. Ye Y, Xie H, Zeng Y, Zhao X, Tian Z, Zhang S. Association between subclinical hypothyroidism and blood pressure--a meta-analysis of observational studies. Endocr Pract. 2014; 20(2): 150-8. https://doi.org/10.4158/EP13237.OR.

22. Adrees M, Gibney J, El-Saeity N, Boran G. Effects of 18 months of L-T4 replacement in women with subclinical hypothyroidism. Clin Endocrinol. 2009; 71(2): 298-303. https://doi.org/10.1111/j.13652265.2008.03509.x

23. Christ-Crain M, Meier C, Guglielmetti M, Huber PR, Riesen W, Staub JJ, et al. Elevated C-reactive protein and homocysteine values: cardiovascular risk factors in hypothyroidism? A cross-sectional and a doubleblind, placebo-controlled trial. Atherosclerosis. 2003; 166(2): 379-86.

24. Caraccio N, Ferrannini E, Monzani F. Lipoprotein profile in subclinical hypothyroidism: response to levothyroxine replacement, a randomized placebocontrolled study. J Clin Endocrinol Metab. 2002; 87(4):

1533-8. https://doi.org/10.1210/jcem.87.4.8378 